\title{
PRODUÇÃO CIENTÍFICA SOBRE CATOLICISMO POPULAR NO BRASIL: ALGUNS APONTAMENTOS
}

\author{
Jadir Souza ${ }^{1}$ \\ Márcia Guena dos Santos ${ }^{2}$
}

\begin{abstract}
RESUMO
O presente artigo tem como objetivo construir o estado da arte sobre Catolicismo Popular Sertanejo com a finalidade de entender como foram tratadas as religiosidades indígenas e de matrizes africanas. Utiliza-se como banco de dados para as buscas o Catálogo de Teses e Dissertações da Coordenação de Aperfeiçoamento de Pessoal de Nível Superior-CAPES. Busca-se compreender como as teses de doutorado produzidas e disponibilizadas entre 2017 e 2021 tratam o tema catolicismo popular e como conceituam tal tema e seus desdobramentos. $\mathrm{O}$ artigo apresenta ainda uma breve reflexão sobre as contribuições de negros e indígenas à formação do Catolicismo Popular Sertanejo e as permanências destes povos nessa manifestação. Observa-se uma concentração maior de produções sobre o catolicismo popular na região centrooeste e nos cursos ligados às Ciências da Religião.
\end{abstract}

Palavras-chave: Revisão de literatura. Catolicismo popular. Catolicismo popular sertanejo. Herança negra. Herança indígena.

\section{SCIENTIFIC PRODUCTION ON POPULAR CATHOLICISM IN BRAZIL: SOME NOTES}

\begin{abstract}
This article aims to build the state of the art on Popular Sertanejo Catholicism in order to understand how indigenous religiosities and African matrices were treated. The Theses and Dissertations Catalog of the Coordination for the Improvement of Higher Education PersonnelCAPES is used as a database for searches. The aim is to understand how the doctoral theses produced and made available between 2017 and 2021 deal with the theme of popular Catholicism and how they conceptualize this theme and its consequences. The article also presents a brief reflection on the contributions of blacks and indigenous peoples to the formation of Sertanejo Popular Catholicism and the permanence of these peoples in this manifestation. There is a greater concentration of productions on popular Catholicism in the Midwest region and in courses related to the Sciences of Religion.
\end{abstract}

Keywords: Literature review. Popular Catholicism. Sertanian popular catholicism. Black heritage. Indigenous Heritage.

\section{PRODUCCIÓN CIENTÍFICA SOBRE EL CATOLICISMO POPULAR EN BRASIL: ALGUNAS NOTAS}

\section{RESUMEN}

\footnotetext{
${ }^{1}$ Doutora em História. Docente do DCH-III (UNEB). Juazeiro-BA. Brasil. mguena @ uneb.br.. ${ }^{2}$ Jornalista. Mestrando pelo PPGESA (UNEB). Juazeiro-BA Brasil. 
Este artículo tiene como objetivo construir el estado del arte sobre el Catolicismo Popular Sertanejo para comprender cómo se trataron las religiosidades indígenas y las matrices africanas. Se utiliza el Catálogo de Tesis y Disertaciones de la Coordinación de Perfeccionamiento del Personal de Educación Superior-CAPES como base de datos para las búsquedas. El objetivo es comprender cómo las tesis doctorales producidas y puestas a disposición entre 2017 y 2021 abordan el tema del catolicismo popular y cómo conceptualizan este tema y sus consecuencias. El artículo también presenta una breve reflexión sobre los aportes de los negros e indígenas a la formación del Catolicismo Popular Sertanejo y la permanencia de estos pueblos en esta manifestación. Existe una mayor concentración de producciones sobre catolicismo popular en la región del Medio Oeste y en cursos relacionados con las Ciencias de la Religión.

Palabras clave: Revisión de literatura. Catolicismo popular. Catolicismo popular sertanejo. Herencia negra. Herencia indígena.

\section{Introdução}

A religiosidade popular tem sido, ao longo das últimas décadas, objeto de estudos de muitos pesquisadores. Vários são os trabalhos que apresentam manifestações, celebrações e práticas religiosas, especialmente do catolicismo popular e suas variações, descrevendo-as e inventariando-as. No entanto, ainda é tímida a produção científica sobre as dimensões identitárias dos e das protagonistas dessa religiosidade.

A partir disso, nota-se a necessidade de catalogar estas produções, sistematizando-as com base nos conceitos apresentados, a fim de traçar uma compreensão melhor consolidada sobre este fenômeno da religiosidade brasileira. Nesta perspectiva, a revisão de literatura se mostra um importante método que pode ser utilizado com o objetivo de traçar um panorama da produção científica acerca do tema.

O presente artigo se pauta nesta proposta de elaborar uma revisão de literatura sobre o catolicismo popular, identificando como o tema tem sido tratado pelos vários autores que se dedicam a estudá-lo. Foram analisados os trabalhos produzidos e publicados no Catálogo de Teses e Dissertações da Coordenação de Aperfeiçoamento de Pessoal de Nível Superior-CAPES, entre os anos de 2017 e 2021.

A partir disso, este artigo propõe também uma breve reflexão sobre os processos de apagamento dos saberes indígenas e africanos na constituição da religiosidade popular. É objeto de interesse desta investigação as permanências das experiências sagradas desses povos nas manifestações do catolicismo popular e como essa continuação é fruto de um processo de resistência à colonialidade da fé empreendida 
pelos invasores europeus, pela Igreja Católica e pelo Estado, em diferentes momentos, ao longo de séculos.

\section{O que há de produção recente sobre o catolicismo popular?}

O presente levantamento é um esforço inicial na busca por respostas às perguntas que balizam a pesquisa intitulada: "Santas Maria e Augustinha: a descolonização da fé pela educação", desenvolvida no âmbito do Programa de PósGraduação Mestrado Multidisciplinar em Educação, Cultura e Territórios Semiáridos PPGESA. Os questionamentos que orientam tal investigação se dão em torno do catolicismo popular e sua prática no nordeste brasileiro: como se formou o catolicismo popular? Quais são suas características? Existe um Catolicismo Popular Sertanejo? O que o diferencia? Quais as influências de negros e indígenas na constituição destas manifestações?

Em uma busca incipiente por tais respostas, lança-se mão neste trabalho de uma revisão de literatura que são
estudos que analisam a produção bibliográfica em determinada área temática, dentro de um recorte de tempo, fornecendo uma visão geral ou um relatório do estado-da-arte sobre um tópico específico, evidenciando novas idéias, métodos, subtemas que têm recebido maior ou menor ênfase na literatura selecionada. (NORONHA; FERREIRA apud MOREIRA, 2004, p. 22)

Desta forma, optou-se, neste momento embrionário da investigação, por selecionar como banco de dados o Catálogo de Teses e Dissertações da Coordenação de Aperfeiçoamento de Pessoal de Nível Superior-CAPES. Fez-se a busca direta pelos termos "catolicismo popular", restringindo os resultados às teses de doutorado produzidas nos últimos cinco anos (2017, 2018, 2019, 2020 e 2021) e disponíveis no catálogo. A busca, com tais parâmetros, retornou 13 teses. No entanto, duas não estavam disponíveis para leitura ou download e uma não apresentou aderência ao tema buscado e, portanto, foi descartada. Desta forma, foram analisadas 10 teses, que estão listadas no quadro 1.

Assim, pode-se classificar a presente revisão de literatura como expositiva, já que expõe o tema a partir da análise de outras pesquisas; questionadora, na medida em 
que busca possibilidades para a expansão da pesquisa sobre o tema; de base, pois serve servirá de apoio à pesquisa principal e funcionará como suporte referencial para a dissertação; temporal, porque foi definido um período específico para a busca; de atualização, pois busca-se publicações recentes e mais significativas sobre o assunto; e, por fim, considerando o tratamento e abordagem, esta revisão de literatura classifica-se como bibliográfica. (MOREIRA, 2004)

O quadro 1 elenca as teses analisadas, apresentando seus autores, títulos, ano de defesa, tipo de produção e instituição a que está vinculada.

\section{Quadro $1^{3}$}

\begin{tabular}{|c|c|c|c|c|}
\hline Autoria & Título & Ano & Curso & Instituição \\
\hline $\begin{array}{l}\text { DIAS, Júlio } \\
\text { César Tavares }\end{array}$ & $\begin{array}{l}\text { Cosme e Damião: aproximações e } \\
\text { tensões no campo religioso } \\
\text { brasileiro }\end{array}$ & 2017 & $\begin{array}{l}\text { Ciência da } \\
\text { Religião }\end{array}$ & $\begin{array}{l}\text { Universidade Federal } \\
\text { de Juiz de Fora }\end{array}$ \\
\hline $\begin{array}{l}\text { SILVA, } \\
\text { Washington } \\
\text { Maciel da }\end{array}$ & $\begin{array}{l}\text { A festa dos Reis Magos: tradição e } \\
\text { modernização na microrregião do } \\
\text { sudoeste de Goiás }\end{array}$ & 2018 & $\begin{array}{l}\text { Ciências } \\
\text { da Religião }\end{array}$ & $\begin{array}{l}\text { Pontifícia } \\
\text { Universidade } \\
\text { Católica de Goiás }\end{array}$ \\
\hline $\begin{array}{ll}\text { GAMA, } & \text { Rafael } \\
\text { da }\end{array}$ & $\begin{array}{l}\text { "Por uma religião nacional": a } \\
\text { separação entre igreja e estado e a } \\
\text { disputa religiosa entre católicos e } \\
\text { protestantes em Belém do Pará } \\
(1889-1931)\end{array}$ & 2019 & História & $\begin{array}{l}\text { Pontifícia } \\
\text { Universidade } \\
\text { Católica de São Paulo }\end{array}$ \\
\hline $\begin{array}{l}\text { MARTINS } \\
\text { FILHO, José } \\
\text { Reinaldo Felipe }\end{array}$ & $\begin{array}{l}\text { Música e identidade no catolicismo } \\
\text { popular em Goiás: um estudo sobre } \\
\text { a Folia de Reis e a Romaria ao } \\
\text { Divino Pai Eterno. }\end{array}$ & 2019 & $\begin{array}{l}\text { Ciências } \\
\text { da Religião }\end{array}$ & $\begin{array}{l}\text { Pontifícia } \\
\text { Universidade } \\
\text { Católica de Goiás }\end{array}$ \\
\hline $\begin{array}{l}\text { NEVES, Gilvan } \\
\text { Gomes das }\end{array}$ & $\begin{array}{l}\text { "O passado é a morte das coisas": } \\
\text { Padre Ibiapina: ante } \\
\text { esquecimento, a memória em } \\
\text { construção }\end{array}$ & 2019 & $\begin{array}{l}\text { Ciências } \\
\text { da Religião }\end{array}$ & $\begin{array}{l}\text { Universidade } \\
\text { Católica } \\
\text { Pernambuco }\end{array}$ \\
\hline $\begin{array}{l}\text { OLIVEIRA, } \\
\text { Marlene Flauzina }\end{array}$ & $\begin{array}{l}\text { Festa de Nossa Senhora da Abadia } \\
\text { em Jatai/GO: uma experiência de } \\
\text { interpretação geográfica }\end{array}$ & 2019 & Geografia & $\begin{array}{l}\text { Universidade Federal } \\
\text { da Grande Dourados }\end{array}$ \\
\hline $\begin{array}{l}\text { OLIVEIRA, } \\
\text { Paulo Wendell } \\
\text { Alves de }\end{array}$ & $\begin{array}{l}\text { Ser-tão romeiro: a memória } \\
\text { hierofânica do catolicismo popular } \\
\text { sertanejo e sua espacialização em } \\
\text { Juazeiro do Norte-CE }\end{array}$ & 2019 & Geografia & $\begin{array}{l}\text { Universidade Federal } \\
\text { de Goiás }\end{array}$ \\
\hline $\begin{array}{l}\text { SILVA, Aerton } \\
\text { Alexandre } \\
\text { Carvalho }\end{array}$ & $\begin{array}{l}\text { A construção de um taumaturgo: a } \\
\text { prática missionária de Frei Damião } \\
\text { de Bozzano no nordeste brasileiro } \\
(1931-1997)\end{array}$ & 2019 & $\begin{array}{l}\text { Ciências } \\
\text { da Religião }\end{array}$ & $\begin{array}{l}\text { Universidade } \\
\text { Católica } \\
\text { Pernambuco }\end{array}$ \\
\hline $\begin{array}{ll}\text { VAZ, } & \text { Rafael } \\
\text { Araldi } & \end{array}$ & $\begin{array}{l}\text { Deus e o Diabo no Sertão da Terra } \\
\text { Firme: imaginário, subjetivação e } \\
\text { poder nas fronteiras do sagrado } \\
\text { (planalto catarinense - 1892-1920) }\end{array}$ & 2019 & História & $\begin{array}{l}\text { Universidade Federal } \\
\text { de Santa Catarina }\end{array}$ \\
\hline MONTELES, & Ecossonâncias: o protagonismo da & 2020 & Performan & Universidade Federal \\
\hline
\end{tabular}

${ }^{3}$ Fonte: tabela elaborada pelo autor. 2021 


\begin{tabular}{|l|l|l|l|l|}
\hline $\begin{array}{l}\text { Nayara Joyse } \\
\text { Silva }\end{array}$ & mulher no tambor de crioula & & $\begin{array}{l}\text { ces } \\
\text { Culturais }\end{array}$ & de Goiás \\
\hline
\end{tabular}

\subsection{Descrição}

Apesar de as 10 teses analisadas fazerem alguma relação com o catolicismo nãooficial, apenas duas se debruçam sobre a conceituação e formação histórica do catolicismo popular. Neves (2019) e Oliveira (2009) vão além e conceituam e discutem o Catolicismo Popular Sertanejo. As outras pesquisas utilizam os conceitos de catolicismo popular de forma tangencial, como suporte teórico às análises empreendidas nas investigações.

É o caso de Dias (2017), autor da tese: "Cosme e Damião: aproximações e tensões no campo religioso brasileiro". A pesquisa investiga a distribuição de balas e doces na celebração aos santos nas cidades de Igarassu (PE) e Salvador (BA) e como esta tradição se constitui no catolicismo popular, nas religiões afro-brasileira e no neopentecostalismo. Nota-se, de partida, que o catolicismo popular não se constitui em discussão basilar à tese, apesar disso o autor aponta alguns conceitos sobre o tema, sugerindo-o como uma consequência do sincretismo religioso.

Nesta concepção, e utilizando o entendimento de Hoonaert, Dias (2017) defende que

\footnotetext{
houve no Brasil diferentes sincretismos católicos: o catolicismo guerreiro trazido pelos colonizadores portugueses, o catolicismo patriarcal vivido nos engenhos e nas regiões de minério e o catolicismo popular, uma interpretação original do catolicismo efetuada por negros, índios e mestiços. (p.94)
}

De maneira pouco detida, o autor aponta ainda como características do catolicismo popular - e o faz apenas como uma das explicações à devoção a Cosme e Damião - a paga de promessas a santos e o estabelecimento de relações de obrigações com as figuras santificadas. (DIAS, 2017)

Gama (2019) vai além e apresenta um conceito mais coeso de catolicismo popular na tese intitulada: “Por uma religião nacional': a separação entre Igreja e Estado e a disputa religiosa entre católicos e protestantes em Belém do Pará (18891931)"”. A pesquisa apresenta o esforço para o reconhecimento do cristianismo como 
religião nacional e os embates ocorridos entre o catolicismo e o protestantismo nesse processo. Para Gama (2019), o catolicismo popular é

um conjunto de crenças e práticas que fazem parte de um catolicismo pluralizado. Práticas socialmente reconhecidas como católicas, de que partilham sobretudo os não especialistas do sagrado, quer pertençam as classes subalternas ou às classes dominantes, mas que não são inicialmente vinculadas a Igreja Católica como instituição. (p. 25)

O autor identifica uma apropriação do movimento pentecostal de um traço do catolicismo popular como forma de se comunicar com o povo paraense, predominantemente católico. Esta característica absorvida é, segundo o autor, a da sobrenaturalidade, através de questões de cura, do “falar em outras línguas" e o “"poder' de efetuar 'milagres"”. (GAMA, 2019, p. 175)

Essa característica ocultista também é identificada por Monteles (2020) ao descrever a forma de acesso (através da permissão de entidades) aos altares de santos presentes nas casas de coreiras do tambor de crioula. "É uma mistura de catolicismo popular com eclesial, no qual, de modo particular, parece existir uma série de nuances com histórias ocultas. Assim, a prática do catolicismo popular faz com que coexistam práticas do dito e do não dito”. (MONTELES, 2020, p. 163)

A autora se dedica a investigar a performance cultural do tambor de crioula e a atuação das coreiras em rodas voltadas para São Benedito em cidades do Maranhão. Monteles (2020) não se detém na discussão sobre catolicismo popular. Ela opta por trabalhar o conceito de catolicismo negro.

Do contato existente entre o catolicismo e as religiões do congo emergem os conflitos e algumas aproximações, isso revela, principalmente, o modo como as relações são tecidas. Assim, conforme Filho (2012, p. 12), "legitima a nossa crença que o catolicismo negro é uma das matrizes religiosas, originárias dos africanos e seus descendentes no Brasil, que alimentam a luta pela cidadania negra no Brasil". (p. 88)

Em "Música e identidade no catolicismo popular em Goiás: um estudo sobre a Folia de Reis e a Romaria ao Divino Pai Eterno”, Martins Filho (2019) apresenta um panorama conceitual e histórico do catolicismo popular a fim de investigar um perfil 
identitário deste, a partir da música como elemento constitutivo. Para o autor, a tensão entre um catolicismo da oficialidade e outro de bases populares é fundamental na conceituação do catolicismo não-oficial.

essa é a raiz de interpretação para as demais definições por nós encontradas, sempre assinaladas por uma lógica binominal. [...] No mesmo sentido, outros binômios utilizados são: "catolicismo vulgar" versus "catolicismo erudito", "catolicismo iletrado" versus "catolicismo letrado", "catolicismo rural" versus "catolicismo urbano". (MARTINS FILHO, 2019, p. 18, 19)

Para o autor, a verdadeira marca do catolicismo popular é o elemento gerador desta fé, ou seja, o povo, as camadas populares, "que tomam como seu o empreendimento da fé" (p. 19). Martins Filho (2019) identifica três traços principais do catolicismo popular:

estreita relação entre o céu e a terra reforçada pela ênfase na devoção aos santos e à Virgem Maria, o uso de representações e imagens que dão vazão à imaginária popular e, por fim, a festa como espaço privilegiado para o exercício da religiosidade, numa constante alternância entre os ditames do sagrado e do profano." (p.108)

As primeiras duas características apontadas por Martins Filho (2019) também são citadas e a terceira perpassa toda a tese "Festa de Nossa Senhora da Abadia em Jataí/GO: uma experiência de interpretação geográfica", de Oliveira (2019). A autora investigou as territorialidades e identidades que surgem e se estabelecem das relações sociais durante os festejos a Nossa Senhora da Abadia. Para Oliveira (2019), os eventos que envolvem a celebração se fundamentam nos princípios do catolicismo popular e se constituem de rituais religiosos sagrados e profanos.

A autora apresenta as definições de catolicismo popular por três autores: Queiroz (1973), que se refere a catolicismo rústico, que tem "um esquema religioso básico, formado de ritos, crenças, cultos dos santos e uma hierarquia de 'agentes do culto"” (apud OLIVEIRA, M.F., 2019, p. 44); Brandão (2004), que trata por catolicismo popular e aponta que este tem características do catolicismo institucional; e Rosendahl (2005), que também se refere por catolicismo popular e chama atenção para a liderança religiosa assumida por leigos que atuam na ausência de padres e bispos. (OLIVEIRA, M. F., 2019) 
Oliveira (2019) aponta, ao longo do texto, marcas do catolicismo popular que perpassam as festividades de Nossa Senhora da Abadia, mas não se detém a explorá-las. São citadas as trocas e distribuição de serviços religiosos, a comunicação e expressão de alguns ritos pela música e a alternação e complementariedade entre o sagrado e o profano, além da devoção aos santos e culto às representações imagéticas destes, como já citado. (OLIVEIRA, 2019)

Outra tese analisada foi a de Silva (2018), intitulada: "A festa dos Reis Magos: tradição e modernização na microrregião do sudoeste de Goiás". Na pesquisa, o autor relaciona os festejos aos Reis Magos ao catolicismo popular, sendo aqueles uma prática deste. Apesar disso, Silva não se debruça sobre a investigação das origens, conceitos e constituições do catolicismo popular, circunscrevendo a discussão à questão sincrética. O autor define assim o catolicismo popular:

Não quer dizer que, a força da imposição colonial impediu a veiculação de práticas religiosas com novos gestos, símbolos e ritos, que mantiveram a crença e a religiosidade como resistência ao contexto de escravidão e opressão. Esse é o sincretismo religioso em funcionamento, um conjunto de práticas e religiosidades como resistência ao cotidiano, uma expressão social da crença e da tradição. No qual, a devoção constrói e reconstrói a prática segundo a vivência daquele que crê, seja opressora ou não. (SILVA, 2018, p. 75)

Vaz (2019) também abordou o catolicismo popular em sua tese: "Deus e o Diabo no Sertão da Terra Firme: imaginário, subjetivação e poder nas fronteiras do sagrado (Planalto Catarinense - 1892-1920)". No entanto, o tema também não é central em sua pesquisa, que se dedica a investigar as práticas de subjetivação e tecnologias de poder mobilizadas através do imaginário religioso. Assim, o catolicismo popular figura apenas em exemplos que demonstram como a burocracia da igreja acionou determinados mecanismos para criar no imaginário coletivo uma forma de sagrado "limpa".

Por sua vez, a ação dos padres na relação com o catolicismo popular será o de gerir conteúdos imagéticos, subtraindo os elementos simbólicos considerados supersticiosos, higienizando e normalizando o conteúdo devocional, produzindo uma gestão do imaginário, constituindo assim um regime de sacralidade." (VAZ, 2019, p. 152)

Outra tese analisada que apresenta discussões sobre o catolicismo popular é a de Silva (2019), que tem o título de: “A construção de um taumaturgo: a prática ComSertões, Juazeiro, Bahia, v. 9, n. 1, p. 73-90, ago. 2021 
missionária de Frei Damião de Bozzano no nordeste brasileiro (1931-1997)”. A pesquisa investiga como foi construída a figura do frade capuchino como santo, a partir de registros e memórias de devotos.O autor trabalha o conceito de catolicismo popular, pensando-o sempre a partir do nordeste.

Partindo da perspectiva das Ciências da Religião, percebemos que o Nordeste brasileiro vivenciou, ao longo dos séculos, um Catolicismo Popular, ou rústico, que se caracteriza por ser um conjunto de representações e práticas religiosas, ligando o ser humano ao sobrenatural, pela intercessão dos santos independentemente da ingerência dos religiosos institucionais. O termo popular busca distinguir cultural e socialmente um povo e também um comportamento religioso que se diferencia do oficial. No Brasil, o Catolicismo Popular revela-se por atos concretos ligados ao cotidiano, tais como rezar, para pedir chuva; benzer uma pessoa doente. Junto a isso, destaca-se o culto aos santos, procurando uma resposta positiva para os seus problemas e reinterpretando os preceitos do catolicismo oficial. (SILVA, 2019, p. 144)

O autor vai além das discussões apresentadas até agora ao propor (não de forma inédita) o conceito de Catolicismo Popular Sertanejo (grafado com iniciais maiúsculas). Para Silva (2019), este seria o catolicismo popular praticado no nordeste, com características familiares, vivenciado pelas classes subalternas e em áreas rurais.

O conceito de Catolicismo Popular Sertanejo também é trabalhado por Neves (2019) na tese “"O passado é a morte das coisas' - Padre Ibiapina: ante o esquecimento, a memória em construção". Na pesquisa, o autor apresenta a vida do Padre Ibiapina, problematizando o esquecimento que houve da história e da atuação do padre nos sertões nordestinos durante cerca de 100 anos e como essa história foi reavivada nos dias atuais. Esta é uma das teses que se debruça mais sobre a formação do catolicismo popular.

Neves (2019) apresenta as várias denominações dadas ao que se conhece correntemente como catolicismo popular. Segundo o autor, Queiroz (2003) vai chamar de catolicismo rústico; Cascudo (1985) se refere a catolicismo ignorante; e Costa e Silva (1982) vai denominar de catolicismo sertanejo. (NEVES, 2019, p. 97). Neves define catolicismo popular como sendo

uma religião caracterizada pelo misticismo. Espontâneo, criativo, leigo, dispensando a mediação sacramental e doutrinal da instituição eclesial e seu principal representante - o padre -, o catolicismo 
popular procura proteção através de um contato imediato com o sagrado - na sua fascinação e repulsa - que ele encontra na natureza e na história, realizando, assim, uma ressignificação da vida cotidiana. (2019, p. 96)

O autor segue a discussão sobre o catolicismo não-oficial dedicando uma subseção ao Catolicismo Popular Sertanejo. Para Neves (2019), assim como para Silva (2019), este catolicismo popular que leva a adjetivação de sertanejo é aquele praticado no nordeste, que tem características próprias que o diferenciam daquele praticado em outras regiões do país. Para o autor, a figura do conselheiro é central no Catolicismo Popular Sertanejo e "é profundamente marcada pela tradição dos beatos e beatas, segundo o costume dos sertanejos, com suas cantorias e rezas populares; além disso, ele é também caracterizado pelo medo do diabo e pelo hábito de rezar o terço e o ofício." (p. 96)

No desenrolar da escrita, o autor defende que as formas de manifestação de crenças e ritos religiosos se renovam no Catolicismo Popular Sertanejo. No entanto, apesar dessas transformações, os praticantes desta religião seguem necessitando da intermediação do catolicismo romano em alguns rituais, como nos sacramentos. Apesar disso, Neves (2019) chama a atenção para o processo de censura e condenação da Igreja Oficial para com os adeptos do catolicismo popular, inclusive o sertanejo.

atitude da Igreja Oficial muitas vezes é condenatória, repressiva, através das ações adotadas pelo clero em relação a essas manifestações do povo e seus fenômenos religiosos 'heterodoxos'; só recentemente, a Igreja se tornou mais tolerante. Mesmo assim, documentos como o de Puebla (1979, p.451) usam expressões como "purificar a religião do povo", criando, assim, uma situação confusa para o povo católico, que, de um lado, segue, com maior ou menor interesse, as diretrizes e imposições eclesiásticas oficiais, mas, por outro lado, esconde fatos por medo de censura. (NEVES, 2019, p. 99)

O conceito de catolicismo popular sertanejo (desta feita, com iniciais em minúsculo) também é discutido em outra tese selecionada para análise. Em "Sert-tão romeiro: a memória hierofânica do catolicismo popular sertanejo e sua espacialização em Juazeiro do Norte-CE”, Oliveira (2019) analisa a construção da ideia de memória hierofânica, com base no sistema religioso do catolicismo popular sertanejo em Juazeiro do Norte-CE. 
Oliveira (2019) propõe a reflexão sobre o catolicismo popular sertanejo a partir de uma perspectiva histórica da formação do território e da sociedade brasileiros, considerando processo de colonização impetrado na época da invasão ao que viria a ser o Brasil. Essa incursão europeia ao atual Brasil foi marcada, segundo o autor, por "uma função perversa da apropriação colonial, exploração dos nativos e destituição das suas terras, acompanhada de genocídios e etnocídios" (OLIVEIRA, 2019, p. 102), com efetiva participação da Igreja.

Nesse cenário, o catolicismo popular se constitui como uma forma de prática do catolicismo ligada aos grupos marginalizados, formados, especialmente, pelos indígenas colonizados e negros escravizados. Esses grupos ressignificaram a religião oficial, apesar do controle rígido por parte da oficialidade da Igreja, e promoveram um processo de criatividade religiosa da evangelização do povo pelo povo. (OLIVEIRA, 2019)

Posto isso, o catolicismo popular não deve ser reduzido a uma mera avaliação da dominação colonial - ao fazermos isso, perdemos a possibilidade de compreensão da força do que é o fenômeno do catolicismo popular. Sua compreensão deve partir do entendimento de sua originalidade que se deve à ressignificação dos símbolos, dos ritos, dos signos, das crenças, etc.. (OLIVEIRA, 2019, p.109)

No nordeste, esse catolicismo popular vai se revestir de características específicas, já apresentadas através de outros autores aqui trabalhados, o que se constitui no catolicismo popular sertanejo. Oliveira (2019) identifica como período de fortalecimento desta forma de catolicismo meados do século XIX, com a separação política entre o Estado e Igreja e a consequente disputa por poder entre ambos. Esse cenário distanciou ainda mais as classes populares do catolicismo romanizado, fazendo com que a religião popular se tornasse cada vez mais autônoma (OLIVEIRA, 2019). Com base nesse distanciamento entre a Igreja Católica e o povo sertanejo, o que se via era a ação de leigos pregando a fé, o que permitiu o desenvolvimento dos sistemas de crenças, símbolos, ritos e signos do catolicismo popular sertanejo em detrimento da religião oficial. (p. 116)

\subsection{Comparação entre os trabalhos}

A análise dos trabalhos selecionados evidencia uma concentração de produções na região centro-oeste, com destaque para as pesquisas realizadas em cursos de 
universidades de Goiás. Observa-se também um número baixo de pesquisas (20\% das teses analisadas) que se dedicam a conceituar e a traçar um panorama histórico da formação dessas religiosidades populares. Nota-se também que as produções são frutos de pesquisas empreendidas em cursos de pós-graduação em Ciências da Religião e suas variações (50\% dos textos), seguidos dos cursos na área de História (20\% das teses) e Geografia (também 20\%), conforme demonstrado no gráfico abaixo.

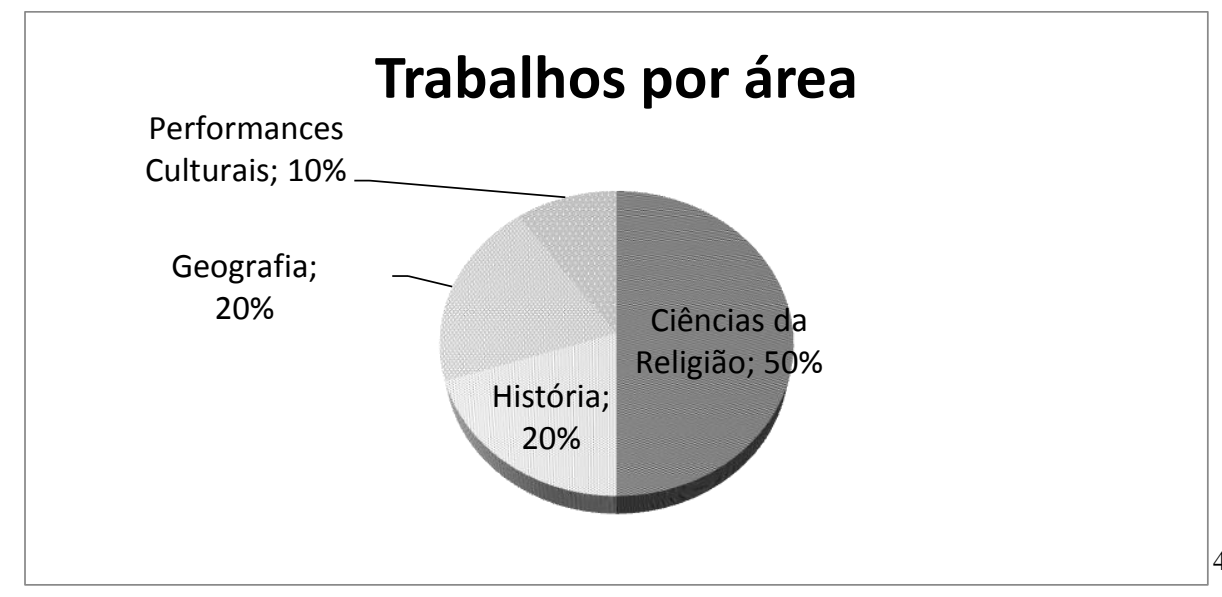

O levantamento aponta caminhos que podem ser seguidos na pesquisa que enseja esta revisão de literatura, como, por exemplo, o aprofundamento das discussões sobre a formação do Catolicismo Popular Sertanejo e as permanências negras e indígenas neste. $O$ presente artigo não se propõe a esgotar a reflexão sobre tais temas, mas na próxima seção indicaremos caminhos que podem ser seguidos no desenvolvimento da investigação, no tocante às contribuições dos povos nativos e escravizados à constituição do Catolicismo Popular Sertanejo.

\section{Negros, indígenas e o Catolicismo Popular Sertanejo}

Quando os europeus chegaram ao Brasil, existiam mais de 1500 povos indígenas espalhados pelo território invadido (LUCIANO, 2006). Com a escravidão de africanos em solo brasileiro, o país recebeu, entre 1500 e 1850, cerca de 4,9 milhões de negros escravizados, trazidos de várias regiões da África. (GOMES, 2019).

Foi nesse cenário que o Catolicismo Oficial encontrou as culturas indígena e negra e lançou estratégias de dominação sobre esses povos, servindo de braço do império na invasão e colonização do território brasileiro. "Primeiramente, essa ação 
cultural se fixou pelo entendimento da falta de almas dos povos escravizados; depois, pela imposição e aculturação religiosa como mecanismo de inclusão dos dominados." (MOREIRA, 2018, p. 46)

Nos sertões nordestinos, esse processo de imposição de uma fé, de uma civilização pretensamente superior, de valores e hábitos europeus resultou em um apagamento de marcas identitárias dos povos colonizados. "Vítima de toda essa construção perversa, a identidade dos sertanejos e sertanejas mestiços, negros, indígenas ou brancos pobres foi forjada muda e silenciada." (MOREIRA, 2018, p. 46).

Martin-Barbero (2001), analisando os dispositivos de hegemonia, vai identificar processos como o que aconteceu na formação do Catolicismo Popular Sertanejo como uma forma não só de reação, mas de resistência dos saberes populares, o que, no caso do Brasil, se refere agudamente aos conhecimentos negro e indígena. Para fazer essa avaliação, Martín-Barbero recorre à figura alegórica da bruxa:

A bruxa sintetiza para os clérigos e os juízes civis, para os homens ricos e os cultos, o mundo que é preciso abolir. Porque é um mundo descentrado, horizontal e ambivalente que entra em conflito radical com a nova imagem do mundo que esboça a razão: vertical, uniforme e centralizado. $O$ saber mágico - astrológico, medicinal ou psicológico - permeia inteiramente o conceito popular do mundo. [...] Esse caráter de dominação, isto é, de ruptura entre progresso e libertação, as classes populares perceberam muito antes de que fosse convertido em discurso político, o perceberam e o enfrentaram a seu modo nos movimentos que resistiram à enculturação. (p. 144, 145, 147)

O Catolicismo Popular Sertanejo surge como estratégia de resposta e resistência ao processo de extermínio de saberes de indígenas e negros. Essa expressão de fé vai modificar o Catolicismo Oficial, a partir dos saberes originários, para que este atenda às necessidades do cotidiano. Essa adaptação vai resultar em manifestações em que as práticas ritualísticas de negros e indígenas estão presentes. (OLIVEIRA, 2019)

A lista de manifestações do Catolicismo Popular, especialmente do Sertanejo, que envolvem saberes herdados dos ameríndios brasileiros e dos africanos escravizados é extensa: as rezas e bênçãos, o culto a santos populares não-canônicos, rituais em harmonia com a natureza e seus elementos, entre outros. Essas são algumas das formas 
como as culturas africana e indígena encontraram de resistir frente à opressão promovida pela religião do colonizador branco.

Tomemos como objeto de reflexão as rezas e bênçãos como forma de cura. Essas práticas de cuidado surgem, provavelmente na Idade Média, e no Brasil colônia tomam a forma como conhecemos hoje: uso de ritos religiosos, gestuais e orais, com o uso de ervas (ALVES, 2016). No Brasil, esses rituais de cura encontram um ambiente em que tanto africanos, quanto indígenas têm nas plantas um meio de alcançar o restabelecimento da saúde, tanto no campo físico ou espiritual.

Para se ter uma ideia desse cenário em que a prática das rezas se desenvolve no país, os indígenas locais, quando da invasão portuguesa ao território que se tornou o Brasil, "já conheciam mais de 2 mil plantas medicinais" (LUCIANO, 2006, p. 177). Os africanos que foram trazidos para cá e habitaram tanto o litoral quanto os sertões, têm, tradicionalmente, nas plantas um dos elementos mais potentes na concentração no àse, que é "o princípio que torna possível o processo vital.” (SANTOS, 2002, p. 39).

Esta relação íntima e ritualística com as plantas leva-nos a pensar outro aspecto do Catolicismo Popular Sertanejo que também está relacionado com a presença dos saberes de indígenas e negros: a relação estabelecida com a natureza. (SANTOS, 2002; LUCIANO, 2006). No modo como o sertanejo exerce o seu catolicismo, tem uma intimidade muito significativa com os elementos e fenômenos naturais, seja na interpretação dos sinais do cosmos ou pela crença da influência de rituais nos eventos da natureza, como chuva ou ventos.

Por isso, não são raras manifestações religiosas populares que surgem e se constituem a partir da observação da natureza. Têm-se como exemplo o culto às santas populares Maria e Augustinha, que ocorre no povoado de Poções, interior de JuazeiroBA e mobiliza centenas de fieis todos os dias 2 de novembro, data dedicada às santas. A memória coletiva local aponta que as irmãs santas morreram na região durante uma viagem e, no ponto onde foram enterradas, nasceram duas árvores de angico (Anadenanthera colubrina ${ }^{5}$ ) que permanecem sempre verdes, mesmo nos períodos de estiagem prolongada. Para os fieis, essa manutenção do aspecto verde, mesmo durante a

${ }^{5}$ https://ainfo.cnptia.embrapa.br/digital/bitstream/item/190109/1/Livro-Nordeste-740-745.2018.pdf ComSertões, Juazeiro, Bahia, v. 9, n. 1, p. 73-90, ago. 2021 
seca, tem um caráter miraculoso, o que levou à devoção às irmãs e a atribuição de outros eventos milagrosos. (SOUZA, 2020)

Apesar das contribuições dos povos originários e dos africanos, não se deve simplificar a constituição do Catolicismo Popular Sertanejo como uma sobreposição dos conhecimentos distintos de cada povo.

O catolicismo que se enraíza no Brasil está marcado por sua origem europeia, mas também pelo encontro que essa tradição teve aqui com as tradições africanas e indígenas. Sua originalidade, contudo, deve ser buscada mais na forma como se realiza esse encontro do que na soma dos elementos dessas culturas. Ou seja, acreditamos que o encontro das culturas advenientes com autóctone produziu um modo partilhado de a cultura popular pensar a relação entre o sagrado e o profano. (STEIL apud MOURA, 2009 p. 57)

Mesmo com todas essas características apontadas (e foi apenas uma amostra), os saberes indígenas e africanos no Catolicismo Popular Sertanejo não são reconhecidos como tal. Esse "esquecimento" está presente também em outras esferas da sociedade, para além do campo acadêmico/científico. A posição e as ações do colonizador explicam esse processo à medida que, primeiro pela Igreja como braço do Estado, e depois este próprio através de medidas jurídicas perseguem e sufocam, principalmente, as práticas religiosas negras, mas também indígenas. Primeiro pela negação da "alma" a esses povos e da salvação através do batismo e da catequese (e, portanto, da negação da fé originária), depois por um arcabouço legal que criminalizava a práticas religiosas africanas. (CAMPOS; KOURYH, 2015)

\section{Considerações finais}

As discussões acadêmicas em torno do catolicismo popular são muitas e variadas. Por isso, a revisão de literatura se mostra uma ferramenta importante para se conhecer o estado das reflexões, os aspectos que estão sendo investigados e as possibilidades de futuros estudos. Neste contexto, o levantamento feito no Catálogo de Teses e Dissertações da Coordenação de Aperfeiçoamento de Pessoal de Nível Superior-CAPES para o presente artigo apontou caminhos importantes para a continuidade dos estudos sobre o catolicismo popular, em especial aquele praticado no nordeste e que tem características específicas e, por isso, chamado de sertanejo. 
Outra possibilidade observada a partir da revisão de literatura é o aprofundamento das reflexões sobre as contribuições de negros e indígenas à formação do catolicismo popular. Interessa-nos, especialmente, os processos de colonialidade da fé, na perspectiva decolonial, e de dominação e aniquilamento dos saberes dos povos nativos e escravizados no campo da religião. Outro ponto importante e que precisa ser explorado são as permanências dos elementos contributivos desses povos no catolicismo popular em perspectiva histórica até à contemporaneidade.

Este artigo apresenta discussões embrionárias acerca desse aspecto. Observa-se, de acordo com o presente estudo, que muitos elementos dos conhecimentos afroameríndios brasileiros estão envolvidos na concepção histórica e no exercício cotidiano e atual do catolicismo popular. No entanto, estes são apontamentos que merecem aprofundamento da reflexão.

Dito isto, compreende-se a necessidade de estudos que se proponham a investigar o catolicismo popular sob uma ótica decolonial, buscando compreender os processos históricos para além da necessidade de se traçar uma linha do tempo na constituição desta forma de exercício da fé. O desafio é refletir esses processos, desde a invasão europeia até a contemporaneidade, a partir da perspectiva das classes subalternizadas.

\section{Referências}

ALVES, Maria Jeane dos Santos. Terapêutica popular: a "cura" pelas benzedeiras enquanto modo de cuidado. 2016. 102 f. Tese (Doutorado) - Curso de Psicologia Clínica, Universidade Católica de Pernambuco, Recife, 2016.

CAMPOS, Zuleica Dantas Pereira; KOURYH, Jussara Rocha. Religiões Afrobrasileiras: perseguições antigas e novas. Revista de Teologia e Ciência da Religião, Recife, v. 5, p. 161-177, dez. 2015. Disponível em: http://www.unicap.br/ojs/index.php/theo/article/view/609/527. Acesso em: 01 jun. 2021.

DIAS, Júlio César Tavares. Cosme e Damião: aproximações e tensões no campo religioso brasileiro. Tese (Doutorado em Ciência da Religião), Universidade Federal de Juiz de Fora, Juiz de Fora, 2017. Disponível em: https://sucupira.capes.gov.br/sucupira/public/consultas/coleta/trabalhoConclusao/viewT rabalhoConclusao.jsf?popup=true\&id_trabalho=5875955. Acesso em: 24 jun. 2021 . 
GAMA, Rafael da. "Por uma religião nacional": a separação entre igreja e estado e a disputa religiosa entre católicos e protestantes em Belém do Pará (1889-1931). Tese (Doutorado em História), Pontifícia Universidade Católica de São Paulo, São Paulo, 2019. Disponível em:

https://sucupira.capes.gov.br/sucupira/public/consultas/coleta/trabalhoConclusao/viewT rabalhoConclusao.jsf?popup=true\&id_trabalho=7722458. Acesso em: 24 jun. 2021.

GOMES, Laurentino. Escravidão: do primeiro leilão de cativos em portugal até a morte de zumbi dos palmares. Rio de Janeiro: Globo Livros, 2019. 1 v.

LUCIANO, Gersem dos Santos. O índio brasileiro: o que você precisa saber sobre os povos indígenas no Brasil de hoje. Brasília: MEC/SECAD; LACED/Museu Nacional, 2006, p. 128-171.

MARTIN-BARBERO, Jesús. Dos meios às Mediações: Comunicação, cultura e hegemonia. Tradução de Ronaldo Politoet al. 2 ed. Rio de Janeiro: Editora UFRJ, 2001.

MARTINS FILHO, José Reinaldo Felipe. Música e identidade no catolicismo popular em Goiás: um estudo sobre a Folia de Reis e a Romaria ao Divino Pai Eterno. Tese (Doutorado em Ciências da Religião), Pontifícia Universidade Católica de Goiás, Goiânia, 2019. Disponível em:

https://sucupira.capes.gov.br/sucupira/public/consultas/coleta/trabalhoConclusao/viewT rabalhoConclusao.jsf?popup=true\&id_trabalho=7644184. Acesso em: 24 jun. 2021 .

MONTELES, Nayara Joyse Silva. Ecossonâncias: o protagonismo da mulher no tambor de crioula. Tese (Doutorado em Performances Culturais), Universidade Federal de Goiás, Goiânia, 2020. Disponível em:

https://sucupira.capes.gov.br/sucupira/public/consultas/coleta/trabalhoConclusao/viewT rabalhoConclusao.jsf?popup=true\&id_trabalho=10068630. Acesso em: 24 jun. 2021.

MOREIRA, Gislene. Sertões Contemporâneos: Rupturas e Continuidades no Semiárido. Salvador, BA: Eduneb/Edufba, 2018.

MOREIRA, Walter. Revisão de Literatura e Desenvolvimento Científico: conceitos e estratégias para confecção. Janus, Lorena-Sp, v. 1, n. 1, p. 21-30, 2004. Disponível em: http://unifatea.com.br/seer3/index.php/Janus/article/view/102/92. Acesso em: 26 jun. 2021.

MOURA, Elen Cristina Dias de. Entre ramos e rezas: o ritual de benzeção em São Luiz do Paraitinga, de 1950 a 2008. 2009, 208 p. Dissertação (Mestrado em Ciências da Religião) - Pontifícia Universidade Católica de São Paulo, São Paulo, 2009. Disponível em: http://www.dominiopublico.gov.br/download/texto/cp099784.pdf. Acesso em 06 nov. 2020.

NEVES, Gilvan Gomes das. "O passado é a morte das coisas": padre ibiapina: ante o esquecimento, a memória em construção. Tese (Doutorado em Ciências da Religião), Universidade Católica de Pernambuco, Recife, 2019. Disponível em: 
http://tede2.unicap.br:8080/bitstream/tede/1131/2/gilvan_gomes_neves.pdf. Acesso em: 24 jun. 2021.

OLIVEIRA, Marlene Flauzina. Festa de Nossa Senhora da Abadia em Jatai/GO: uma experiência de interpretação geográfica. Tese (Doutorado em Geografia), Universidade Federal da Grande Dourados, Dourados-MS, 2019. Disponível em: https://sucupira.capes.gov.br/sucupira/public/consultas/coleta/trabalhoConclusao/viewT rabalhoConclusao.jsf?popup=true\&id_trabalho=7881399. Acesso em: 24 jun. 2021.

OLIVEIRA, Paulo Wendell Alves de. Ser-tão romeiro: a memória hierofânica do catolicismo popular sertanejo e sua espacialização em Juazeiro do Norte-CE. Tese (Doutorado em Geografia), Universidade Federal de Goiás, Goiânia, 2019. Disponível em:

https://sucupira.capes.gov.br/sucupira/public/consultas/coleta/trabalhoConclusao/viewT rabalhoConclusao.jsf?popup=true\&id_trabalho=8015676. Acesso em: 24 jun. 2021 .

SANTOS, Juana Elbein dos. Os nagô e a morte: pàde, àsèsè e o culto égun na bahia. 11. ed. Petropólis: Vozes, 2002.

SILVA, Aerton Alexander de Carvalho. A construção de um taumaturgo: a prática missionária de frei damião de bozzano no nordeste brasileiro (1931-1997). Tese (Doutorado em Ciências da Religião), Universidade Católica de Pernambuco, Recife, 2019. Disponível em:

https://sucupira.capes.gov.br/sucupira/public/consultas/coleta/trabalhoConclusao/viewT rabalhoConclusao.jsf?popup=true\&id_trabalho=7876468. Acesso em: 24 jun. 2021.

SILVA, Washington Maciel da. A festa dos Reis Magos: tradição e modernização na microrregião do sudoeste de goiás. Tese (Doutorado em Ciências da Religião), Pontifícia Universidade Católica de Goiás, Goiânia, 2018. Disponível em: https://sucupira.capes.gov.br/sucupira/public/consultas/coleta/trabalhoConclusao/viewT rabalhoConclusao.jsf?popup=true\&id_trabalho=7268992. Acesso em: 24 jun. 2021.

SOUZA, Jadnaelson da Silva. Santas Maria e Augustinha: a representação popular da fé de uma comunidade. In: WORKSHOP NACIONAL DE EDUCAÇÃO CONTEXTUALIZADA PARA A CONVIVÊNCIA COM O SEMIÁRIDO BRASILEIRO, 9., 2020, Juazeiro. Anais [...]. Juazeiro: Universidade do Estado da Bahia. Ppgesa, 2020. p. 166-170. Disponível em: https://5613d587-67bb-4147-bade095fde2ad02f.filesusr.com/ugd/c2492e_fcfa2efd0c414bb98dc3ee7b861575d3.pdf?inde $\mathrm{x}=$ tru. Acesso em: 01 jun. 2021.

VAZ, Rafael Araldi. Deus e o Diabo no Sertão da Terra Firme: imaginário, subjetivação e poder nas fronteiras do sagrado (planalto catarinense - 1892-1920). Tese (Doutorado em História), Universidade Federal de Santa Catarina, Florianópolis, 2019. Disponível em:

https://sucupira.capes.gov.br/sucupira/public/consultas/coleta/trabalhoConclusao/viewT rabalhoConclusao.jsf?popup=true\&id_trabalho=7808682. Acesso em: 24 jun. 2021. 
